\title{
Nexus between foreign direct investment and economic growth in Bangladesh: an augmented autoregressive distributed lag bounds testing approach
}

\author{
Bibhuti Sarker ${ }^{1,2^{*}}$ and Farid Khan ${ }^{3}$
}

*Correspondence: sarkerb@ myumanitoba.ca

'Department of Economics, University of Manitoba, Winnipeg, Manitoba, Canada

${ }^{2}$ Department of Economics, Bangabandhu Sheikh Mujibur Rahman Science and Technology University, Gopalganj 8100 Bangladesh

Full list of author information is available at the end of the article

\begin{abstract}
The relationship between foreign direct investment (FDI) inflows and economic growth in host countries is a heavily debated issue. Although some studies have found evidence of the positive impact of FDI on economic growth, others have revealed the opposite result. Studies that examined the causality between FDI and gross domestic product (GDP) also have found evidence of unidirectional causality and, in some cases, a bidirectional causality. This study investigated the causal nexus between FDI and GDP in Bangladesh by employing standard time-series econometric tools, namely, augmented Dickey-Fuller, augmented Dickey-Fuller generalized least square, Kwiatkowski-Phillips-Schmidt-Shin, and Lee-Strazicich unit root tests to check stationarity, augmented autoregressive distributed lag (augmented ARDL) bounds testing approach to check cointegration, and Granger causality to explore the direction of causality. The augmented ARDL model found a long-run relationship between FDI and GDP. In addition, the error correction model and Granger causality results indicated the presence of a unidirectional causality running from GDP to FDI.
\end{abstract}

Keywords: FDI, GDP, Augmented ARDL, Causality, Economic growth

JEL classification: $\mathrm{C} 22, \mathrm{~F} 31, \mathrm{O} 47$

\section{Introduction}

Foreign direct investment (FDI) is one of the most significant factors to influence economic growth in a developing country like Bangladesh, where capital is scarce because of insufficient domestic savings-both private and public. This investment is crucial for the much-needed industrialization in a country (Mujeri and Chowdhury 2013). In the absence of adequate local investment, FDI has been attracted from industrially advanced countries to accelerate the path of industrialization, to foster and maintain sustained economic growth, and to reduce the level of unemployment (Hussain and Haque 2016). In addition, the effectiveness of FDI in the host countries depends on the efficiency of domestic investment (Razin and Sadka 2003).

Gradually, countries are becoming more integrated to achieve faster economic growth and are opening up for free trade as a result of globalization (Middleton 2007). Economic and technological factors drive the growth of international production,

(c) The Author(s). 2020 Open Access This article is distributed under the terms of the Creative Commons Attribution 4.0 International License (http://creativecommons.org/licenses/by/4.0/), which permits unrestricted use, distribution, and reproduction in any medium, provided you give appropriate credit to the original author(s) and the source, provide a link to the Creative Commons license, and indicate if changes were made. 
which is facilitated by the liberalization of trade policies and increased FDI flows. In this context, globalization provides an unparalleled opportunity for developing countries to foster and achieve economic growth through trade and investment (Arndt 1999). Hence, many countries-especially the least developed countries-are implementing liberal economic policies to encourage more capital inflows from developed countries (Bengoa and Sanchez-Robles 2003).

Today, the importance of FDI has increased in the form of technology transfer and market networks that can result in efficient production and sales globally (Lipsey and Sjöholm 2010; Urata 1998). Over the past few decades, FDI inflows also have increased remarkably in developing countries. Foreign investors benefit by utilizing their assets and resources efficiently through FDI, while the recipients are expected to benefit by securing technologies and becoming involved in international trade networks (Louzi and Abadi 2011). The question, therefore, naturally arises as to whether these FDI inflows have any impact on local development, and vice versa. This issue, therefore, demands an empirical inquiry (Figlio and Blonigen 2000). Because gross domestic product (GDP) is one of the measures of the level of development, this study aims to explore the relationship between FDI and GDP in Bangladesh.

FDI often is considered to be an important vehicle for economic growth (Vu Le and Suruga 2005a, b). A vast majority of empirical studies have focused on the effect that FDI may exert on economic growth along with the causal link from FDI to growth. As noted by Chakraborty and Basu (2006), however, the causal link from economic growth to FDI and the feedback relationship deserve further attention. Therefore, the direction of this relationship between FDI and economic growth needs to be stressed because the FDI-related spillover effect of knowledge encourages economic growth, which, in turn, attracts more FDI (Chakraborty and Basu 2006).

Empirical studies, such as Vu Le and Suruga (2005a, b), Durham (2004), Borensztein et al. (1998), and Balasubramanyam et al. (1996), have investigated the FDI-growth nexus. They have stressed that the possibility of a positive impact of FDI on economic growth depends on such mechanisms as the technology-upgrading progress, human capital investment, absorptive capacity, and trade policy adopted by the host country (Gönel and Aksoy 2016; Katircioglu 2009; Silajdzic and Mehic 2016). These studies generally considered a panel of countries, suggesting that FDI can have a positive but indirect effect on economic growth. In contrast, in the case of India, Vu Le and Suruga (2005a, b) suggested that FDI, public capital, and private investment all played important roles in promoting economic growth. They also advocated against uncontrolled spending in public capital expenditure, which can impede the positive effects of FDI in a country.

The mobility of capital and technology is the single most important reason for lowincome countries to grow at a higher rate (Li and Chen 2010). The stability of FDI inflows and required macroeconomic and financial adjustments have been identified as the contributing factors for economic growth in developing countries (Chao et al. 2019; Sridharan et al. 2009). The issue that FDI enhances and accelerates economic growth has not received common empirical support. The positive effect that FDI may exert on economic growth may start only if the financial market, an interdependent system with a broad and interconnected network (Kou et al. 2019), is developed more than at a threshold level (Azman-Saini et al. 2010). The positive impact of FDI and foreign trade 
on economic growth may be realized only by the FDI inflows in the economies that are expected to grow faster and follow open-trade policies (Adhikary 2010; Shimul et al. 2009). FDI has been channeled effectively by transferring technology and promoting economic growth in developing countries within the framework of the neoclassical models (Bitzer and Kerekes 2008; Solow 1956; Sridharan et al. 2009). Therefore, the host countries should facilitate a financial liberalization and stabilization policy before experiencing any increase in FDI (De Gregorio and Guidotti 1995).

Bashir (1999) found that foreign firms tended to increase the level of human capital and accelerate the growth rate of an economy. It has been argued that although the effect varies across geographic regions and over time, FDI, for the most part, has led to economic growth. Feridun (2004) conducted a study on the causality between FDI and GDP per capita in Cyprus and found strong evidence of GDP being Granger caused by FDI, but not vice versa. Results further suggested that Cyprus's capacity to achieve progress on economic development will depend on how much the country attracts foreign capital (Borensztein et al. 1998). Moreover, Wu (2000) emphasized the development of infrastructure, growth of the non-state sector, and economic reform for host economies to realize the positive effects of FDI.

The internationalization theory implies that FDI takes place in countries as multinational corporations are replacing external markets with more efficient internal markets (Asghar et al. 2012; Dunning 1977; Rugman 1985, 1986). Empirically, a lot of disagreement has been observed in the relationship between FDI and economic growth as most of the studies either have provided mixed results or have failed to reach any definite conclusions (Borensztein et al. 1998; Carkovic and Levine 2002). Various empirical studies have focused on the significant role played by FDI inflows to foster economic growth of the developing countries through its contribution of human resources, capital formation, and enhanced organization and managerial skills, as well as the transfer of technologies because of their scarce capital (Aitken and Harrison 1999; Barro 1990; Blomstrom and Wolff 1989; Markusen and Venables 1999; Zhang 2001). To date, the existing empirical evidence on the relationship between FDI and economic growth nexus has not been conclusive. Therefore, this has become the basis for academics and policy makers to analyze this relationship further using recent developments in econometric modeling (Asghar et al. 2012).

Figure 1 shows GDP and FDI inflows (in million US dollars and natural logarithm) in Bangladesh over the period from 1972 to 2017. The amount of FDI inflows was not significant until 1996. This may be partly due to the fact that the country was ruled by a long-held military regime, and that year, a democratic government was formed. The volume of FDI inflows increased gradually from 2002 onward with little fluctuation. In recent years, the growth rate of FDI inflows in Bangladesh has declined, although it is considered to be a potent vehicle for economic development. The Seventh Five-Year Plan (2016-2020), however, set a target of FDI increase of $\$ 5.87$ billion by 2018 . Figure 1 exhibits the increasing trend in both variables, which confirms that GDP increases gradually over the considered time period. The growth rate of GDP increased slightly after 2004 and continued to increase up to recent periods, with an average growth rate of $6.0 \%$ or more (Bangladesh Bank 2017).

The previous literature on FDI and economic growth nexus in Bangladesh, for example, Shimul et al. (2009), using a smaller dataset (1973-2007), utilized the ARDL 


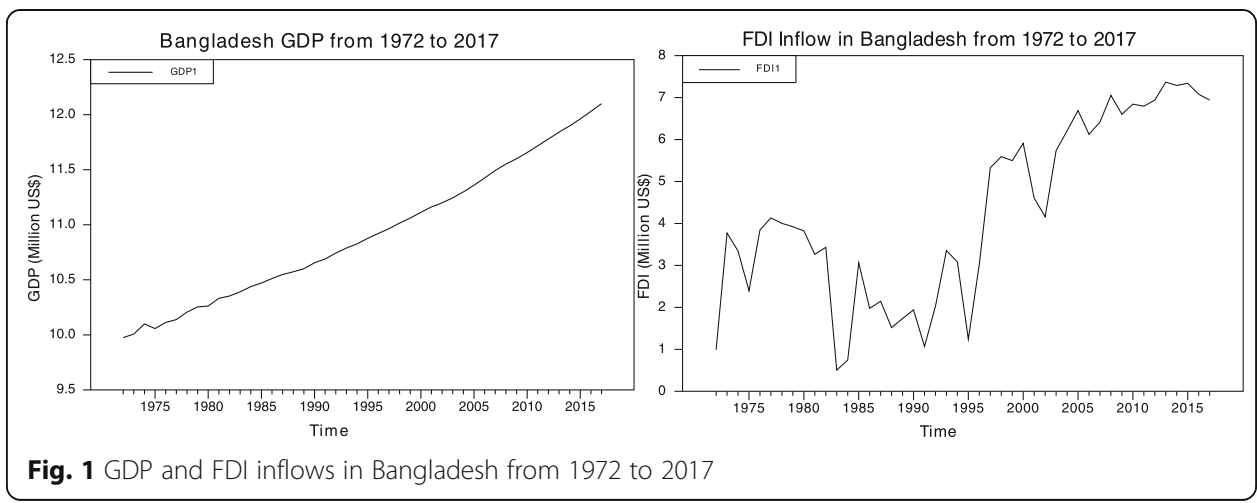

technique, and found no causal relationship between FDI and economic growth. Conversely, Tabassum and Ahmed (2014), using data for the period 1972-2011 and applying a multiple regression model, found FDI to be insignificant in influencing economic growth. Therefore, the literature is limited on the selected topic in the case of Bangladesh. In addition, the FDI and economic growth relationship is one of the debatable issues in the literature, which needs further investigation. This study, however, used a longer dataset (1972-2017) than previous studies. It revealed the causal nexus between FDI and economic growth in Bangladesh by applying appropriate time-series econometric tools and robustness check techniques. Therefore, this study filled in the gap in the literature using relatively upgraded time-series econometric techniques and a newer and larger dataset.

The remainder of this study is organized as follows: Section 2 provides a brief overview of data and the methodology used to analyze the results. In section 3 , empirical results based on the time-series econometric methodology are presented and discussed in detail. Section 4 gives the conclusion and recommendations of this study.

\section{Data and methodology}

To explore the relationship between the two variables, FDI and GDP in Bangladesh, this study used data collected from the World Bank's World Development Indicators database. The data series included annual data (in millions of U.S. dollar) for both FDI and GDP covering the period from 1972 to 2017. We took the GDP variable as a real series measured in constant 2000 U.S. dollars. We took FDI as a net inflow and converted it to a real unit by applying a GDP deflator. We then expressed both series in a natural logarithm.

For econometric analysis, we first applied unit root tests to check for the order of integration of the data series. ${ }^{1}$ Second, we applied the augmented ARDL modeling approach to see whether any long-run relationships existed between the variables. Third, we applied a Granger causality test to determine the direction of causality, that is, whether FDI caused GDP or GDP caused FDI. Finally, we applied several diagnostic tests for a robustness check.

${ }^{1}$ Although the ARDL bounds testing approach can be used for a data series without knowing the order of integration (i.e., it can be applied to a mixture of $I(1)$ and $I(0)$ series), it is inappropriate for a series of $I(2)$. See, for example, Pesaran et al. (2001) for more details. 


\section{Unit root tests}

To test for stationarity of the time-series data, FDI, and GDP, we applied augmented Dickey-Fuller (ADF), augmented Dickey-Fuller generalized least square (DF-GLS), Kwiatkowski-Phillips-Schmidt-Shin (KPSS), and Lee-Strazicich (LS) unit root tests. We applied the KPSS test because some series are, in fact, trend stationary instead of having unit roots (Kwiatkowski et al. 1992). Figure 1 shows some broken trends in the FDI series. Hence, we applied the Lee and Strazicich (2013) unit root test, which allowed for one structural break in both the null and alternative hypotheses, to see whether there were any structural breaks in the data series.

\section{Augmented Dickey-Fuller test}

This ADF test is conducted by augmenting the equation in which the lagged difference form of the dependent variable $\Delta Y_{t-i}$ is added as an explanatory variable to capture any serial autocorrelation (Dickey and Fuller 1981). Following are the three variants of the ADF test.

No constant and no trend:

$$
\Delta Y_{t}=\gamma_{1} Y_{t-1}+\sum_{i=1}^{m} \alpha_{i} \Delta Y_{t-i}+\mu_{t}
$$

Constant and no trend:

$$
\Delta Y_{t}=\gamma_{0}+\gamma_{1} Y_{t-1}+\sum_{i=1}^{m} \alpha_{i} \Delta Y_{t-i}+\mu_{t}
$$

Constant and trend:

$$
\Delta Y_{t}=\gamma_{0}+\gamma_{1} Y_{t-1}+\gamma_{2} t+\sum_{i=1}^{m} \alpha_{i} \Delta Y_{t-i}+\mu_{t}
$$

where $\mu_{t}$ is a pure white noise error term and $\Delta Y_{t}$ is the first difference of the dependent variable. To use a particular model, we need to verify the pattern of the time-series data by observing its diagrammatic representation. If the data series exhibits neither drift nor trend, we can apply Eq. (1); if the data series exhibits drift but no trend, we have to apply Eq. (2); finally, if data series exhibits both drift and trend, we need to apply Eq. (3) (Harris 1992). ${ }^{2}$

\section{DF-GLS unit root test}

The Elliott et al. (1996) study modified the ADF unit root test and termed it the DFGLS test. Before performing this test, the data are transformed using a generalized least squares (GLS) regression. The test has two steps. First, the test de-trends (de-means) the data utilizing the GLS approach; second, the test uses an ADF test to identify a unit root. The DF-GLS test also allows for a linear time trend that is based on the following regression:

${ }^{2}$ To have knowledge about the particular pattern of the data series, we had to plot them in a figure (as in Figure 1). Here both series exhibit the trend; hence, we had to use model 3. 


$$
\Delta y_{t}^{d}=\alpha y_{t-1}^{d}+\sum_{j=1}^{p} \beta_{j} \Delta y_{t-j}^{d}+v_{t}
$$

where $y_{t}^{d}$ is the de-trended (de-meaned) data series and $v_{t}$ is a white noise error term. In addition to the DF-GLS test, the Elliott et al. (1996) study computed a second unit root test, which was termed the point-optimal test. The null hypothesis is the unit root against the alternative stationary.

\section{KPSS test}

Kwiatkowski et al. (1992) proposed a unit root test in which the presence of a unit root is not in the null but in the alternative hypothesis. This test, known as KPSS test, argues that the absence of a unit root is not a necessary proof for the data to be stationary but, by design, may be trend stationary (Lipsey and Sjöholm 2011). The test takes the following time-series model:

$$
\begin{aligned}
& y_{t}=\beta_{0}+\beta_{1} t+\gamma_{t}+\varepsilon_{t}, \text { and } \\
& \gamma_{t}=\gamma_{t-1}+\mu_{t} .
\end{aligned}
$$

Equation (5) has three different components. First, $\beta_{0}$ and $\beta_{1} t$ are deterministic components in the form of a constant term and a linear time trend. Second, $\gamma_{t}$ is either a random walk component or a constant term, which depends on whether or not the variance of $\mu_{t}$, denoted $\sigma_{\mu}^{2}$, takes on a nonzero value. ${ }^{3}$ Finally, $\varepsilon_{t}$ is a disturbance term, that in the current context is assumed to fulfill $\varepsilon_{t}=\omega(L) \xi_{t}$, where $\omega(L)=\sum_{i=0}^{\infty} \theta L^{i}$ such that $0<\omega(1)<\infty$ and $\sum_{i=1}^{\infty} i\left|\theta_{i}\right|<\infty$, while $\sigma_{\xi}^{2}=E\left(\xi_{1}^{2}\right)$. Assumptions on the error process amounts to assuming that the disturbance follows a linear process, as in Phillips and Solo (1992).

To test the null hypothesis that $y_{t}$ is covariance stationary or that is $I(0)$, Kwiatkowski et al. (1992) suggested that whether or not $\sigma_{\mu}^{2}$ is equal to zero should be tested by employing the following test statistic:

$$
L M=\frac{1}{T^{2}} \frac{\sum_{t=1}^{T} M_{t}^{2}}{\hat{\sigma}^{2}},
$$

where $M_{t}=\sum_{i=1}^{t} e_{i}$ is the least squares residual obtained by de-trending the timeseries $y_{t}$ with either an intercept or an intercept and a time trend. In addition, $\hat{\sigma}^{2}$ in Eq. (7) is a variance estimator that can relieve the asymptotic distribution of the Lagrange multiplier (LM) statistic from nuisance parameters under the null hypothesis.

\section{Lee-Strazicich test}

The conventional methods for testing unit roots cannot account for breaks in the data series. Some data series actually may contain breaks either in the intercept or in the slope or in both. Therefore, it is essential to apply a unit root test that allows for structural breaks in the data series. Lee and Strazicich (2013) proposed the minimum LM unit root test, which allows for one structural break under both the null and alternative

\footnotetext{
${ }^{3}$ When the variance is zero, the random walk term will take on the value $\gamma_{0}$ for all $t$, which will alter the constant term of $y_{t}$ to $\beta_{0}+\gamma_{t}$.
} 
hypotheses in a consistent manner. This test can detect structural break in the data series, if any, endogenously. The test considers the following data-generating process:

$$
y_{t}=\alpha^{\ddot{E}} X_{t}+\varepsilon_{t}, \quad \varepsilon_{t}=\theta \varepsilon_{t-1}+e_{t},
$$

where $X_{t}$ includes exogenous variables. Two models of structural change are considered here: Model A, which is known as the crash model, allows for a one-time change in the intercept under the alternative hypothesis; and Model $\mathrm{C}$, which is known as the break model, allows for a shift in the intercept and a change in trend slope under the alternative hypothesis. The crash model can be described by $X_{t}=\left[1, t, D_{t}\right]^{\ddot{E}}$, where $D_{t}=1$ for $t \geq T_{B}+1$ and zero otherwise, whereas the break model can be described by $X_{t}=[1, t$, $\left.D_{t}, D T_{t}\right]^{\ddot{E}}$, where $D T_{t}=t-T_{B}$ for $t \geq T_{B}+1$, and zero otherwise. The minimum LM principle says that a unit root test statistic comes from the following regression:

$$
\Delta y_{t}=\alpha^{\ddot{E}} \Delta X_{t}+\beta \tilde{S}_{t-1}+\mu_{t},
$$

where the de-trended series $\tilde{S}_{t}$ is defined as follows: $\tilde{S}_{t}=y_{t}-\tilde{\delta}_{m}-X_{t} \tilde{\alpha}, t=2, \ldots, T ; \tilde{\alpha}$ equals the coefficients in the regression of $\Delta y_{t}$ onto $\Delta X_{t}$; and $\tilde{\delta}_{m}$ equals $y_{1}-X_{1} \tilde{\alpha}$, where $y_{1}$ and $X_{1}$ correspond to the first observations of $y_{t}$ and $X_{t}$ respectively.

\section{Augmented ARDL bounds testing approach to Cointegration analysis}

To analyze the relationship between GDP and FDI, this study applied an augmented ARDL bounds testing approach to the cointegration proposed by McNown et al. (2018). Although there are various cointegration approaches, such as Engle and Granger (1987), Johansen (1988), and Johansen and Juselius (1990), the data series must have a unique order of integration for these models to be applied. Thus, the ARDL model is more flexible in terms of its application when the data series do not have unique order of integration. This model can be applied to variables that have different order of integration - that is, $I(0)$ or $I(1)$. It is not applicable, however, if any of the variables are $I(2)$. Moreover, for a small dataset, it can be reliably applied to obtain consistent results (Haug 2002). Furthermore, in the case of a lag selection for both the dependent and independent variables, it gives more options and can handle the endogeneity phenomenon in variables, if any exist.

The ARDL model proposed by Pesaran et al. (2001) was upgraded by McNown et al. (2018) and was named the augmented ARDL. This version of the model necessitated an extra $t$-test or $F$-test on the coefficients of lagged independent variables. For our framework, this model is specified in Eq. (10), which we used to reveal the long-run relationship between the considered variables: GDP and FDI.

$$
\begin{aligned}
\Delta \ln G D P_{t}= & \alpha_{1}+\sum_{i=1}^{p} \beta_{1} \Delta \ln G D P_{t-i}+\sum_{i=0}^{q} \beta_{2} \Delta \ln F D \mathrm{I}_{t-i}+\gamma_{1} \ln G D P_{t-1} \\
& +\gamma_{2} \ln F D I_{t-1}+\sigma_{1} D_{t}+\varepsilon_{t}
\end{aligned}
$$

where $\varepsilon_{t}$ is a white noise error term and $\Delta$ is a first difference operator. In Eq. (10), the terms with summation represented short-run dynamics, whereas the terms with $\gamma_{\mathrm{s}}$ indicated long-run relationships. $D_{t}$ is included to account for possible structural break in the dataset. Here, the null hypothesis is $\gamma_{1}=\gamma_{2}=0$, which indicated that no long-run relationship existed. The first test in the ARDL modeling analysis is an $F$-test for the joint 
significance of the coefficients on the level (Pesaran and Shin 1999; Pesaran et al. 2001). The second test is a $t$-test for the lagged dependent variables. The statistics have a nonstandard distribution under the null hypothesis in the sense that no level relationship exists regardless of whether the regressors are $I(0)$ or $I(1)$.

In the case of the ARDL test, however, Goh and McNown (2015) demonstrated that it was insufficient to report only the value of the $F$-test statistic for the overall test and for the $t$-test statistic on a lagged dependent variable. To avoid the degenerate case 1 identified by Pesaran et al. (2001), McNown et al. (2018) proposed an additional $t$-test or $F$-test on the lagged independent variables to complement the ARDL test by Pesaran et al. (2001). The use of all three tests was necessary to distinguish between cases of cointegration or degenerate cases.

Instead of conventional critical values, Pesaran et al. (2001) and Sam et al. (2019) provided two sets of asymptotic critical values: one for purely $I(1)$ and another for purely $I(0)$ regressors. If the value of the $F$-test statistic was smaller than the lower bound critical value or the absolute value of the $t$-test statistic was lower than the absolute lower bound critical value, then the null hypothesis of "no long-run relationship" could not be rejected. This implied that no long-run relationship existed between the variables. In contrast, if the value of the $F$-test statistic was greater than the upper bound critical value or the absolute value of the $t$-test statistic was greater than the absolute upper bound critical value, then the null hypothesis could be rejected. This implied that longrun relationships did exist between the variables. Finally, if the value of the test statistic was neither lower nor greater than the two critical values, that is, the value fell between the two critical values, then the decision regarding the long-run relationships between the variables was inconclusive.

To analyze the short-run dynamics, we applied the following error correction model (ECM):

$$
\Delta \ln G D P=\alpha_{2}+\sum_{i=1}^{p} \theta_{1} \Delta \ln G D P_{t-i}+\sum_{i=0}^{q} \theta_{2} \Delta \ln F D I_{t-i}+\omega E C T_{t-1}+\mu_{t},
$$

where $\theta_{s}$ indicates the short-run dynamics, $E C T$ is the error correction term measuring the speed of adjustment each period toward equilibrium after a shock, and $\omega$ is the corresponding parameter that gives this measure. The expected value of the corresponding parameter of ECT ranges from -1 to 0 , where 0 implies no convergence toward equilibrium and -1 implies perfect convergence, that is, any shock this period is perfectly adjusted the next period if the value is -1 .

We applied several diagnostic tests. First, we applied the Harvey test to check for the heteroscedasticity of the residuals of the augmented ARDL model. Second, we applied the Breusch-Godfrey Serial Correlation LM test to check for serial correlation of the residuals. Third, we used the Ramsey RESET test as a model specification test. Fourth, we utilized the Jarque-Bera normality test to test for the normality of the residuals of the models. Finally, we used the cumulative sum (CUSUM) test and the CUSUM of square test to check for model stability. ${ }^{4}$

\footnotetext{
${ }^{4}$ See Brown et al. (1975) for more details. These tests are developed to test the stability of the estimated parameters, which depend on the cumulative sum of the recursive residuals. These tests find parameters to be stable if the cumulative sum lies between the two $5 \%$ critical straight lines, but if the cumulative sum goes outside the critical lines, the parameters are unstable.
} 


\section{Granger causality}

The cointegration technique can test only whether any relationships exist between the variables, but it cannot give the direction of causality. A unidirectional or bidirectional causality may exist between the variables. To test for the direction of causality, we needed to apply a causality test technique. The Granger representation theorem (Engle and Granger 1987) suggests the direction of causality of two or more variables when they are cointegrated with the error correction being used. The linear regression modeling of the stochastic processes is used as its mathematical basis (Granger 1969). For our two-variable case, FDI and GDP, we can frame the model as follows:

$$
\begin{aligned}
& Y_{t}=\alpha_{0}+\alpha_{1} Y_{t-1}+\ldots+\alpha_{p} Y_{t-p}+\beta_{1} X_{t-1}+\ldots+\beta_{p} X_{t-p}+v_{1, t}, \text { and } \\
& X_{t}=a_{0}+a_{1} X_{t-1}+\ldots+a_{p} X_{t-p}+B_{1} Y_{t-1}+\ldots+B_{p} Y_{t-p}+v_{2, t} .
\end{aligned}
$$

where $\alpha_{1}$ to $\alpha_{p}$ and $a_{1}$ to $a_{p}$ are coefficients for the lagged dependent variables, and $\beta_{1}$ to $\beta_{p}$ and $B_{1}$ to $B_{p}$ are coefficients for the lagged independent variables. First, for both time series, we took the maximum order of integration $(d)$; second, we selected the maximum number of lags by applying the vector autoregression (VAR) lag selection technique; and, third, we added the maximum order of integration $(d)$ for both series to the lags selected by the VAR technique to obtain the total number of lags to be used while applying the Granger causality technique (Granger 1969). The hypotheses are as follows:

$$
\begin{aligned}
& H_{0}: \beta_{1}=\ldots \ldots \ldots \ldots \ldots \ldots \ldots \beta_{p}=0 \text { and indicates } X \text { does not Granger cause } Y . \\
& H_{0}: B_{1}=\ldots \ldots \ldots \ldots \ldots \ldots \ldots B_{p}=0 \text { and indicates } Y \text { does not Granger cause } X .
\end{aligned}
$$

If we reject the null hypothesis, it suggests that one variable Granger causes another variable-that is, the rejection of the null hypothesis " $X$ does not Granger cause $Y$ " indicates that $X$ does Granger cause $Y$. The same logic holds for the second null hypothesis.

\section{Empirical results}

Table 1 shows basic descriptive statistics of lnGDP and lnFDI. The columns display the variables' mean, standard error, minimum value, maximum value, skewness, kurtosis, and Jarque-Bera test for normality check with its corresponding significance values.

\section{Results of unit root}

Although the augmented ARDL bounds test can be applied to variables that have a different order of integration, it must be ensured that no variable is $I(2)$. To check for the order of integration of the FDI and GDP data series, we estimated the unit root tests. A stationary process is one in which the mean and variance are constant over time (Gujarati 2003).

Table 1 Descriptive statistics of the data series

\begin{tabular}{lllllllll}
\hline Series & Mean & Std. Error & Minimum & Maximum & Skewness & Kurtosis & J.B. & $P$-value \\
\hline GDP & 10.9197 & 0.6219 & 9.9746 & 12.1006 & 0.2708 & -1.0788 & 2.7930 & 0.2474 \\
FDI & 4.2798 & 2.14281 & 0.5044 & 7.3681 & -0.0776 & -1.2999 & 3.2850 & 0.1934 \\
\hline
\end{tabular}

Data are expressed in natural logarithm 
Table 2 Results of unit root tests

\begin{tabular}{|c|c|c|c|c|c|c|c|c|}
\hline \multirow{4}{*}{ Variables } & \multicolumn{8}{|c|}{ ADF, DF-GLS, and KPSS test } \\
\hline & \multirow{2}{*}{\multicolumn{2}{|c|}{ ADF }} & \multicolumn{4}{|c|}{ DF-GLS } & \multirow{2}{*}{\multicolumn{2}{|c|}{ KPSS }} \\
\hline & & & \multicolumn{2}{|r|}{$\mathbf{P}_{\mathbf{T}}$} & \multicolumn{2}{|c|}{ GLS } & & \\
\hline & Level & First Dif. & Level & First Dif. & Level & First Dif. & Level & First Diff. \\
\hline GDP & 2.264 & $-11.109 * * *$ & 74.853 & $5.529 * *$ & 0.164 & $-7.772 * * *$ & $0.1577 * *$ & $0.1435^{*}$ \\
\hline FDI & -1.711 & $-7.434 * * *$ & 7.828 & $4.385 * *$ & -2.764 & $-4.598 * * *$ & 0.1179 & 0.1005 \\
\hline \multicolumn{9}{|c|}{ LS (one break model) } \\
\hline & & \multicolumn{3}{|c|}{ Level } & \multicolumn{4}{|c|}{ First Dif. } \\
\hline & Mode & T-Stat & & Break & & Stat & Bre & eak \\
\hline \multirow[t]{2}{*}{ GDP } & Crash & -0.376 & & D: 1980 & & $651 * *$ & D: 1 & 987 \\
\hline & Break & -2.648 & & $\begin{array}{l}\text { D: } 1997 \\
\text { DT: } 1997\end{array}$ & -7. & $50 * * *$ & $\begin{array}{r}\text { D: } 1 \\
\text { DT: } 19\end{array}$ & $\begin{array}{l}1985 \\
985^{* * *}\end{array}$ \\
\hline \multirow[t]{2}{*}{ FDI } & Crash & $-3.921 * *$ & & : $1982 * *$ & & .415 & D: 19 & $982 *$ \\
\hline & Break & -3.437 & & $\begin{array}{c}\text { D: } 1995 \\
\text { DT: } 1995\end{array}$ & & $84 * * *$ & $\begin{array}{c}\text { D: } 1 \\
\text { DT: } 1\end{array}$ & $\begin{array}{l}981 \\
1981\end{array}$ \\
\hline
\end{tabular}

Table 2 (upper panel) shows the results of the unit roots of the time-series data on FDI and GDP based on ADF, DF-GLS, and KPSS unit root tests. ${ }^{5}$ The results showed that the GDP series was nonstationary at level but stationary at first difference according to ADF, DF-GLS, and KPSS ${ }^{6}$ unit root tests. The same results held in both the crash and break model ${ }^{7}$ of the LS test (lower panel). This allowed for one endogenously determined structural break. Thus, in the GDP series, we could not say there was structural break, either in intercept or slope. The FDI series also was nonstationary at level but stationary at first difference (except for the KPSS test in which it was stationary at both level and first difference). The FDI series was stationary at level (at the 5\% level) with a structural break in the intercept in 1982, according to the crash model. It was nonstationary, however, at first difference with the same structural break, which implied that the structural break in 1982 was significant in the series. This break was consistent with the fact that the existing military government in Bangladesh was replaced in 1982 with another military-backed government. This change in power in state administration led to a decline in foreign capital inflows in several subsequent years starting from 1982.

\footnotetext{
${ }^{5}$ Figure 1 exhibits the trend in the original data series; hence, we applied only the trend model (model 3) of the ADF and KPSS unit root tests. The maximum lag length used are 4 for both the ADF and LS tests and 10 for KPSS test.

${ }^{6}$ The null hypothesis for KPSS test is "stationarity" and the alternative is "unit root." See Kwiatkowski et al. (1992) for more details.

${ }^{7}$ The unit root test proposed by Lee and Strazicich (2003) utilized two models to test for the unit root, crash, and break models. We applied the crash model when the data series did not exhibit the trend, and break model was appropriate for the data series that did exhibit the trend.
} 
Therefore, the unit root results gave a mixture of $I(1)$ and $I(0)$ series. Hence, the usual Engle-Granger and Johansen cointegration technique were not appropriate and required a data series to have a unique order of integration. The features of the data series necessitated the use of the augmented ARDL model proposed by McNown et al. (2018). This model could be applied to variables with a different order of integration, that is, a combination of $I(0)$ and $I(1)$.

\section{Augmented ARDL bounds test for Cointegration}

To select the optimal lag length for each variable, we estimated the number of regressions $(p+1)^{k}$ by the ARDL model, where $p$ was the maximum lag length and $k$ was the number of explanatory variables (Shrestha and Chowdhury 2007). Therefore, the number of regressions estimated by ARDL model was $(4+1)^{2}=25{ }^{8}$

\section{The long-run Cointegration analysis}

To test for the long-run relationships between the considered variables, we estimated the augmented ARDL bounds test model, as in Eq. (10). The estimated results confirmed whether any long-run relationship existed between GDP and FDI.

The estimated results are displayed in Table 3. We applied the Akaike information criterion to select the appropriate lag length to be used in the augmented ARDL bounds test from a maximum of four lags for both series. The results of the bounds test confirmed that there was a long-run relationship between the variables because the coefficients were significant. Dum_FDI was dummy variable accounting for possible structural break in the data series. It had a value of 1 for the year 1982 and 0 for all other years (as indicated by LS unit root test). The dummy variable (Dum_FDI), however, was not statistically significant. This lack of significance implied that the structural break identified by the unit root test (LS test) did not affect the independent variable (GDP) significantly.

Table 4 shows the bounds test results of the $F$-test and $t$-test to show the long-run relationships between the variables. The augmented ARDL model was "unrestricted intercepts and no trend" because this was best fit by the diagnostic tests. We have reported the critical values of Pesaran et al. (2001), Narayan (2005), and Sam et al. (2019). We reported the Narayan (2005) critical values because we had a small sample size. The values of the $F$-statistic exceeded all three of the critical values at the $5 \%$ level for the GDP equation and at the $10 \%$ for the FDI equation. Therefore, the results of the $F$-bound test revealed that long-run relationships existed between the variables.

We also reported the $t$-statistic (on the lagged dependent variables) whose absolute values also exceeded the absolute upper bound critical value at the 1\% level for GDP equation and at the $10 \%$ for FDI equation, which implied the existence of a long-run relationship. In addition, to avoid the degenerate case 1 identified by Pesaran et al. (2001), we reported the $t$-test statistic associated with the coefficients on the lagged independent variables. The values of these $t$-test statistics exceeded the absolute upper bound critical value at the $10 \%$ level for both the GDP and FDI equations. Hence, the results removed the possibility of the degenerate cases identified by Pesaran et al. (2001). Therefore, all three test statistics confirmed the evidence of cointegration between the variables.

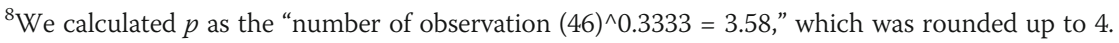


Table 3 Augmented ARDL model estimation results

\begin{tabular}{|c|c|c|c|c|}
\hline Dependent variable & Regressors & Coefficient & Standard Error & T-Statistic \\
\hline \multirow{6}{*}{$\Delta \ln G D P$} & $\ln \mathrm{GDP}_{-1}$ & 0.0685 & 0.0158 & $4.91 * * *$ \\
\hline & $\ln \mathrm{FDI}_{-1}$ & 0.5346 & 0.1400 & $3.82 * *$ \\
\hline & Dum_FDI & -0.0149 & 0.0127 & -1.17 \\
\hline & \multicolumn{4}{|c|}{ R-squared: 0.9997} \\
\hline & \multicolumn{4}{|c|}{ Adjusted R-squared: 0.9996} \\
\hline & \multicolumn{4}{|c|}{$F$-stat: 11076.80} \\
\hline \multirow{5}{*}{$\Delta \ln F D I$} & $\ln \mathrm{FDI}_{-1}$ & -0.3316 & 0.1017 & $-3.26^{* *}$ \\
\hline & $\ln \mathrm{GDP}_{-1}$ & 0.2753 & 0.0793 & $3.47 *$ \\
\hline & \multicolumn{4}{|c|}{ R-squared: 0.8494} \\
\hline & \multicolumn{4}{|c|}{ Adjusted R-squared: 0.8071} \\
\hline & \multicolumn{4}{|l|}{$F$-stat: 20.06} \\
\hline
\end{tabular}

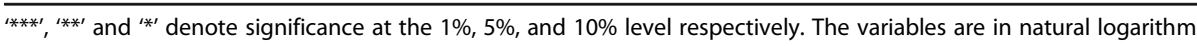

\section{Analysis of short-run dynamics with augmented ARDL bounds test}

We found evidence in favor of short-run dynamics as shown by the signs and values of the coefficients of the first-difference lagged variables, GDP and FDI, and of ECT with their corresponding significant $t$-statistic (Table 5). The coefficient of ECT was positive significant but was very close to zero when the dependent variable was GDP. This result implied that no adjustment was made toward a long-run equilibrium relationship for this equation if there was a shock in the short run. However, the coefficient of ECT was negative significant when the dependent variable was FDI, which implied that there was an adjustment toward a long-run equilibrium relationship for this equation if there was a shock in the short run.

\section{Diagnostic tests}

Table 6 shows the results of different diagnostic tests. To check the heteroscedasticity of the residuals of the augmented ARDL model, we used the Harvey test, and for the correlation check, we used the Breusch-Godfrey test. The results on these two tests revealed

Table 4 Long-run augmented ARDL bounds testing with F-statistic and t-statistic

\begin{tabular}{|c|c|c|c|c|c|c|c|c|}
\hline \multirow[t]{9}{*}{ Critical Values } & \multirow{3}{*}{\multicolumn{2}{|c|}{$\begin{array}{l}\text { Dependent } \\
\text { variable: } \Delta l n \\
\text { GDP }\end{array}$}} & \multicolumn{6}{|c|}{ F-Statistic: $5.63^{* *}$} \\
\hline & & & \multicolumn{6}{|c|}{ t-statistic on lagged dependent variable: $4.91^{* * *}$} \\
\hline & & & \multicolumn{6}{|c|}{$t$-statistic on lagged independent variable: $3.82^{*}$} \\
\hline & \multirow{3}{*}{\multicolumn{2}{|c|}{$\begin{array}{l}\text { Dependent } \\
\text { variable: } \Delta / n \\
\text { FDI }\end{array}$}} & \multicolumn{6}{|c|}{ F-Statistic: $4.48^{*}$} \\
\hline & & & \multicolumn{6}{|c|}{ t-statistic on lagged dependent variable: $-3.26^{*}$} \\
\hline & & & \multicolumn{6}{|c|}{$t$-statistic on lagged independent variable: $3.47^{*}$} \\
\hline & \multicolumn{4}{|c|}{ Pesaran et al. (2001) } & \multirow{2}{*}{\multicolumn{2}{|c|}{ Narayan (2005) }} & \multirow{2}{*}{\multicolumn{2}{|c|}{ Sam et al. (2019) }} \\
\hline & \multicolumn{2}{|c|}{$F$-test } & \multicolumn{2}{|l|}{$t$-test } & & & & \\
\hline & I(0) & $\mathrm{I}(1)$ & $\mathrm{I}(0)$ & $\mathrm{I}(1)$ & $\mathrm{I}(0)$ & $\mathrm{I}(1)$ & $\mathrm{I}(0)$ & $\mathrm{I}(1)$ \\
\hline 1 percentage & 5.15 & 6.36 & -3.43 & -4.10 & 5.8784 & 6.870 & 5.06 & 8.38 \\
\hline 5 percentage & 3.79 & 4.85 & -2.86 & -3.53 & 4.335 & 5.078 & 3.21 & 5.62 \\
\hline 10 percentage & 3.17 & 4.14 & -2.57 & -3.21 & 3.625 & 4.330 & 2.41 & 4.43 \\
\hline
\end{tabular}


Table 5 Augmented ARDL short-run and ECM results

\begin{tabular}{ccccc}
\hline $\begin{array}{c}\text { Dependent } \\
\text { variable }\end{array}$ & Regressors & Coefficients & Standard Error & T-Statistic \\
\hline$\Delta \ln G D P$ & $\Delta \ln \mathrm{GDP}_{-1}$ & -0.3169 & 0.1458 & $-2.17^{* *}$ \\
& $\Delta \ln \mathrm{FDI}$ & 0.0418 & 0.0206 & $2.023^{* *}$ \\
& $\Delta \ln \mathrm{FDI}_{-1}$ & -0.0024 & 0.0014 & $1.74^{*}$ \\
& $\mathrm{ECT}$ & 0.0046 & 0.0008 & $5.7586^{* * *}$ \\
\hline \multirow{2}{*}{$\ln F D I$} & $\Delta \ln \mathrm{FDI}_{-1}$ & -0.0237 & 0.1419 & -0.1670 \\
& $\Delta \ln \mathrm{FDI}_{-2}$ & -0.2875 & 0.1149 & $-2.5022^{* *}$ \\
& $\Delta \ln \mathrm{GDP}$ & 0.0859 & 0.0475 & $1.8084^{*}$ \\
& $\mathrm{ECT}$ & -0.2160 & 0.0985 & $-2.1936^{* *}$ \\
\hline
\end{tabular}

$\overline{\imath * * * \prime},{ }^{\prime * * \prime}$, and ${ }^{\prime * \prime}$ denote significance at the $1 \%, 5 \%$, and $10 \%$ level respectively. The variables are in natural logarithm

that the residuals obtained from the augmented ARDL model were homoscedastic and uncorrelated. For the normality test, the study utilized the Jarque-Bera test, which showed that the residuals of the test employed were normally distributed. Moreover, to check for the appropriate functional form, the study used the Ramsey RESET test. The probability values of 0.5391 and 0.7582 suggested that the models are well specified.

Furthermore, to ensure the stability of the estimated parameters of the long-run relationship of our results, we employed CUSUM and CUSUM of squares tests based on the recursive residuals developed by Brown et al. (1975).

Parameter constancy and model stability were significant if both plots, CUSUM and CUSUM of squares, remained between the $5 \%$ critical bounds. The plots of CUSUM and CUSUM of squares in Fig. 2 (for regression with GDP being the dependent variable) remained between the $5 \%$ critical bounds, thereby indicating "parameter constancy" and "no identified systematic change" in the coefficients at the 5\% significance level in the data series.

Figure 3 shows parameter constancy and model stability. The plots of CUSUM and CUSUM of squares remained between the $5 \%$ critical bounds.

\section{Results of Granger causality}

The results of Granger causality based on Granger (1969) provided evidence to reject the null hypothesis that "GDP does not Granger cause FDI" at the 5\% significance level (Table 7). This result confirmed that GDP Granger caused FDI at the 5\% significance level. The null hypothesis "FDI does not Granger cause GDP," however, cannot be rejected because the probability of the test statistic was 0.1431 , which was greater than even the 10\% significance level. This indicated that GDP was not Granger caused by FDI in the short run. Therefore, there was a short-run unidirectional causality running

Table 6 Results from different diagnostic tests

\begin{tabular}{|c|c|c|c|c|c|c|c|c|}
\hline \multirow{2}{*}{$\begin{array}{l}\text { Dep. } \\
\text { variable }\end{array}$} & \multicolumn{2}{|l|}{ Harvey } & \multicolumn{2}{|c|}{ Breusch-Godfrey } & \multicolumn{2}{|c|}{ Ramsey } & \multicolumn{2}{|c|}{ Jarque-Bera } \\
\hline & F-Stat & Sig. & F-Stat & Sig. & F-Stat & Sig. & Stat & Sig. \\
\hline$\Delta \ln G D P$ & 1.2183 & 0.3168 & 1.3245 & 0.2598 & 0.8267 & 0.6064 & 2.3189 & 0.3137 \\
\hline$\triangle \ln F D \mid$ & 0.6361 & 0.7580 & 0.7264 & 0.6816 & 0.1254 & 0.9987 & 1.6738 & 0.4331 \\
\hline
\end{tabular}



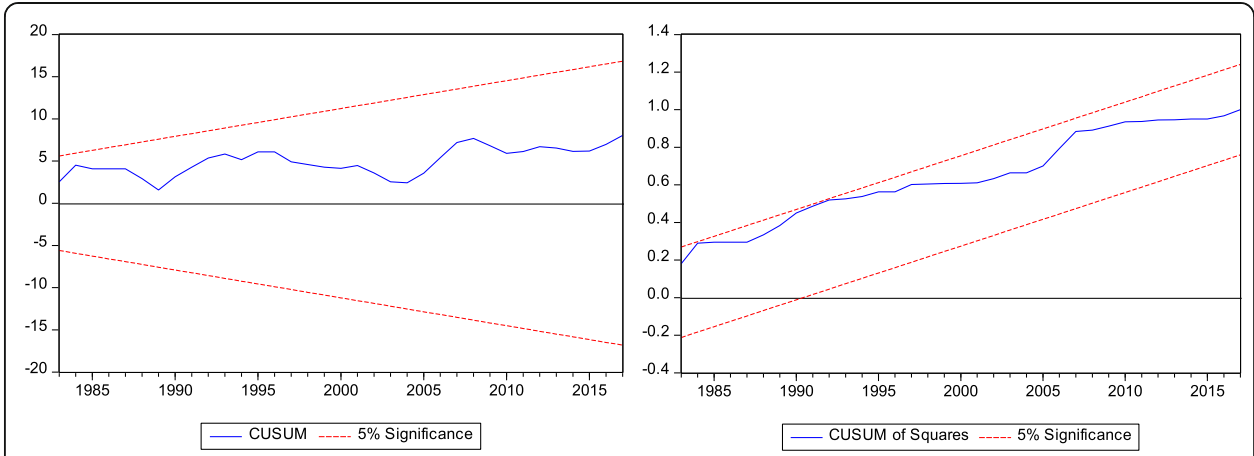

Fig. 2 Plots of CUSUM and CUSUM of squares (dependent variable is GDP)

from GDP to FDI in Bangladesh. These results supported the finding that the steady GDP growth rate could help the Bangladesh economy to attract steady FDI inflows in the long run.

The results of this study, in terms of causality, were similar to that of Chakraborty and Mukherjee (2012), Kivyiro and Arminen (2014), Ozyigit and Eminer (2011), Goh et al. (2017), and Basu et al. (2003). In terms of causality, however, these results were in contrast to the results of Katircioglu (2009), Sunde (2017), Azman-Saini et al. (2010), Shahbaz and Rahman (2010), Ibrahiem (2015), and Wang (2009).

\section{Conclusion and policy recommendations}

This study conducted an empirical analysis of the nexus between FDI and GDP. The empirical results of the augmented ARDL bounds testing approach to cointegration with structural breaks suggested that there was a long-run relationship between GDP and FDI in Bangladesh. The signs and values of ECT coefficients and the values of corresponding $t$-statistic confirmed the existence of this long-run relationship. The ECT results also confirmed the finding that the disequilibrium for the FDI equation converged. The disequilibrium for the GDP equation did not converge if there was any shock in the equilibrium position. This meant that the long-run causality was unidirectional, and it ran from GDP to FDI. Having confirmed that there was a long-run relationship between GDP and FDI through a cointegration analysis, the study applied a Granger causality test, which also indicated the presence of short-run unidirectional causality running from GDP to FDI. These results were consistent, as Bangladesh has

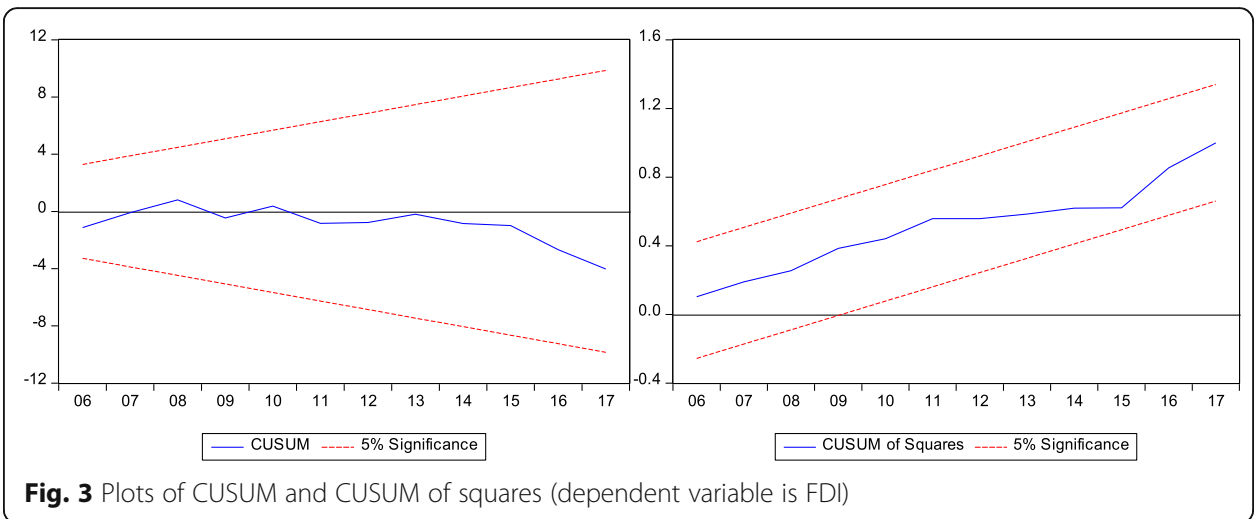


Table 7 Results of Granger Causality

\begin{tabular}{llll}
\hline Null Hypothesis & F-test & Probability & Decision \\
\hline FDI does not Granger Cause GDP & 2.0446 & 0.1431 & Accepted \\
GDP does not Granger Cause FDI & $3.0319^{*}$ & 0.0497 & Rejected \\
\hline
\end{tabular}

${ }^{\prime * \prime}$ denote rejection of the null hypothesis at the $1 \%, 5 \%$, and $10 \%$ level respectively

been experiencing stable economic growth over the past few decades and the volume of FDI also has increased to a significant extent with little fluctuation.

Therefore, the findings of this study have some crucial policy implications. The findings of the presence of short-run and long-run relationships and the causality running from GDP (economic growth) to FDI advocate for placing greater emphasis on policies that are appropriate to maintain a steady growth rate of GDP. Notably, if possible, policy makers in Bangladesh should induce policies required for sound macroeconomic position, develop a socioeconomic infrastructure for the economy, further liberalize the financial sector, and maintain an environment for sound international trade and smooth utilization of foreign investment in Bangladesh. Moreover, policy makers should ensure policies that support the development of human capital, which determines how much manpower the economy is capable of absorbing, and should maintain a sound macroeconomic position. Furthermore, political stability is crucial for a sound macroeconomic position, which is required for the GDP growth rate to be maintained at a steady rate. Finally, the government should ensure that all of the important steps for FDI are utilized fairly and effectively, which is essential in a capital-scarce country like Bangladesh.

\section{Abbreviations}

ADF: Augmented Dickey-Fuller; ARDL: Autoregressive distributed lag; CUSUM: Cumulative sum; DF-GLS: Augmented Dickey-Fuller Generalized Least Square; ECM: Error correction model; ECT: Error correction term; FDI: Foreign direct investment; GDP: Gross domestic product; KPSS: Kwiatkowski Phillips Schmidt Shin; LM: Lagrange Multiplier; LS: Lee-Strazicich; VAR: Vector autoregression

\section{Acknowledgments}

We would like to thank Professor Dilip Kumar Nath for his helpful comments in the early draft of this paper. The authors are grateful to Jon and Dzikpe Francis for their kind help in necessary proofreading. We would also like to thank the anonymous reviewers for their valuable comments that improved the quality of this paper.

Authors' contributions

BS was the major contributor in designing and writing the manuscript. FK provided BS with valuable suggestions and comments in every steps including modeling the econometric framework and result analysis and finally reviewed the manuscript. Both authors read and approved the final manuscript.

Funding

Not applicable.

Availability of data and materials

The data are available on World Bank's World Development Indicators website.

Competing interests

The authors declare that they have no competing interests.

\section{Author details}

${ }^{1}$ Department of Economics, University of Manitoba, Winnipeg, Manitoba, Canada. ${ }^{2}$ Department of Economics, Bangabandhu Sheikh Mujibur Rahman Science and Technology University, Gopalganj 8100, Bangladesh. ${ }^{3}$ Department of Economics, Rajshahi University, Rajshahi 6205, Bangladesh. 
Received: 26 March 2019 Accepted: 26 November 2019

Published online: 06 February 2020

\section{References}

Adhikary BK (2010) FDI, trade openness, capital formation, and economic growth in Bangladesh: a linkage analysis. Int J Bus Manag 6(1):16-28 https://doi.org/10.5539/ijbm.v6n1p16

Aitken BJ, Harrison AE (1999) Do domestic firms benefit from direct foreign investment? Evidence from Venezuela. Am Econ Rev 89(3):605-618 https://doi.org/10.1257/aer.89.3.605

Arndt SW (1999) Globalization and economic development. J Int Trade Econ Dev 8(3):3099-3318 https://doi.org/10.1080/ 09638199900000018

Asghar N, Nasreen S, Rehman H u (2012) Review of Economics \& Finance Relationship between FDI and Economic Growth in Selected Asian Countries : A Panel Data Analysis. Rev Econ Finance 8:84-96

Azman-Saini WNW, Law SH, Ahmad AH (2010) FDI and economic growth: new evidence on the role of financial markets. Econ Lett 107(2):211-213 https://doi.org/10.1016/j.econlet.2010.01.027

Balasubramanyam VN, Salisu M, Sapsford D (1996) Foreign direct investment and growth in EP and is countries. Econ J 106(434):92 https://doi.org/10.2307/2234933

Bangladesh Bank. (2017). The real economy. Retrived from https:/www.bb.org.bd/pub/annual/anr

Barro RJ (1990) Government spending in a simple model of Endogeneous growth. J Pol Econ 98(5, part 2):S103-S125 https:// doi.org/10.1086/261726

Bashir A-HM (1999) Foreign direct investment and economic growth in some MENA countries : theory and evidence. Topics Middle East North Afr Econ Electron J 1 (middle East economic association and Loyola University Chicago) https:// ecommons.luc.edu/cgi/viewcontent.cgi?article=1008\&context=meea

Basu P, Chakraborty C, Reagle D (2003) Liberalization, FDI, and growth in developing countries: a panel Cointegration approach. Econ Inq 41(3):510-516 https://doi.org/10.1093/ei/cbg024

Bengoa M, Sanchez-Robles B (2003) Foreign direct investment, economic freedom and growth: new evidence from Latin America. Eur J Polit Econ 19(3):529-545 https://doi.org/10.1016/S0176-2680(03)00011-9

Bitzer J, Kerekes M (2008) Does foreign direct investment transfer technology across borders? New evidence. Econ Lett 100(3):355-358 https://doi.org/10.1016/j.econlet.2008.02.029

Blomstrom M, Wolff E (1989) Multinational corporations and productivity convergence in Mexico, Cambridge https:/doi.org/ 10.3386/W3141

Borensztein E, De Gregorio J, Lee J-W (1998) How does foreign direct investment affect economic growth? J Int Econ 45(1): 115-135 https://doi.org/10.1016/S0022-1996(97)00033-0

Brown RL, Durbin J, Evans JM (1975) Techniques for testing the Constancy of regression relationships over time. R Stat Soc 37(2):149-192

Carkovic M, Levine RE (2002) Does foreign direct investment accelerate economic growth? SSRN Electron J https://doi.org/10. 2139/ssin.314924

Chakraborty C, Basu P (2006) Foreign Direct Investment and Growth in India: A Cointegration Approach. Appl Econ 34 https://ecommons.luc.edu/cgi/viewcontent.cgi?article=1008\&context=meea

Chakraborty D, Mukherjee J (2012) Is there any relationship between foreign direct investment, domestic investment and economic growth in India? A time series analysis. Rev Mark Integr 4(3):309-337 https://doi.org/10.1177/ 0974929213481712

Chao X, Kou G, Peng Y, Alsaadi FE (2019) Behavior monitoring methods for trade-based MONEY laundering integrating macro and micro prudential regulation: a CASE from China. Technol Econ Dev Econ 25(6):1081-1096 https://doi.org/10. 3846/tede.2019.9383

De Gregorio J, Guidotti PE (1995) Financial development and economic growth. World Dev 23(3):433-448 https://doi.org/10. 1016/0305-750X(94)00132-1

Dickey DA, Fuller WA (1981) Likelihood ratio statistics for autoregressive time series with a unit root. Econometrica 49(4):1057 https://doi.org/10.2307/1912517

Dunning JH (1977) Trade, location of economic activity and the MNE: a search for an eclectic approach. In: The international allocation of economic activity. Palgrave Macmillan UK, London, pp 395-418 https://doi.org/10.1007/ 978-1-349-03196-2_38

Durham JB (2004) Absorptive capacity and the effects of foreign direct investment and equity foreign portfolio investment on economic growth. Eur Econ Rev 48(2):285-306 https://doi.org/10.1016/S0014-2921(02)00264-7

Elliott G, Rothenberg TJ, Stock JH (1996) Efficient tests for an autoregressive unit root. Econometrica 64(4):813 https://doi.org/ $10.2307 / 2171846$

Engle RF, Granger CWJ (1987) Co-integration and error correction: representation, estimation, and testing. Econometrica 55(2):251-276 https://doi.org/10.2307/1913236

Feridun M (2004) Foreign direct investment and economic growth: a causality analysis for Cyprus, 1976-2002. J Appl Sci 4(4): 654-657 https://doi.org/10.3923/jas.2004.654.657

Figlio DN, Blonigen BA (2000) The effects of foreign direct investment on local communities. J Urban Econ 48(2):338-363 https://doi.org/10.1006/juec.2000.2170

Goh SK, McNown R (2015) Examining the exchange rate regime-monetary policy autonomy nexus: evidence from Malaysia. Int Rev Econ Finance 35:292-303 https://doi.org/10.1016/j.iref.2014.10.006

Goh SK, Sam CY, McNown R (2017) Re-examining foreign direct investment, exports, and economic growth in Asian economies using a bootstrap ARDL test for Cointegration. J Asian Econ 51:12-22 https://doi.org/10.1016/ j.asieco.2017.06.001

Gönel F, Aksoy T (2016) Revisiting FDI-led growth hypothesis: the role of sector characteristics. J Int Trade Econ Dev 25(8): 1144-1166 https://doi.org/10.1080/09638199.2016.1195431

Granger CWJ (1969) Investigating causal relations by econometric models and cross-spectral methods. Econometrica 37(3): 424 https://doi.org/10.2307/1912791

Gujarati DN (2003) Basic econometrics. New York: McGraw Hill 
Harris RID (1992) Testing for unit roots using the augmented Dickey-Fuller test. Some issues relating to the size, power and the lag structure of the test. Econ Lett 38(4):381-386 https://doi.org/10.1016/0165-1765(92)90022-Q

Haug AA (2002) Temporal aggregation and the power of Cointegration tests: a Monte Carlo study*. Oxf Bull Econ Stat 64(4): 399-412 https://doi.org/10.1111/1468-0084.00025

Hussain M, Haque M (2016) Foreign direct investment, trade, and economic growth: an empirical analysis of Bangladesh. Economies 4(2):7 https://doi.org/10.3390/economies4020007

Ibrahiem DM (2015) Renewable electricity consumption, foreign direct investment and economic growth in Egypt: an ARDL approach. Procedia Economics and Finance 30:313-323 https://doi.org/10.1016/S2212-5671(15)01299-X

Johansen S (1988) Statistical analysis of cointegration vectors. J Econ Dyn Control 12(2-3):231-254 https://doi.org/10.1016/ 0165-1889(88)90041-3

Johansen S, Juselius K (1990) Maximum likelihood estimation and inference on Cointegration - with applications to the demand for Money. Oxf Bull Econ Stat 52(2):169-210 https://doi.org/10.1111/j.1468-0084.1990.mp52002003.x

Katircioglu S (2009) Foreign direct investment and economic growth in Turkey: an empirical investigation by the bounds test for co-integration and causality tests. Ekonomska Istrazivanja 22(3):1-9 Retrieved from http://www.scopus.com/inward/ record.url?eid=2-s2.0-75949116566\&partnerlD=40\&md5=2eae2f7c4a5d354a0e38996ac218820f

Kivyiro P, Arminen H (2014) Carbon dioxide emissions, energy consumption, economic growth, and foreign direct investment: causality analysis for sub-Saharan Africa. Energy 74:595-606 https://doi.org/10.1016/j.energy.2014.07.025

Kou G, Chao X, Peng Y, Alsaadi FE, Herrera-Viedma E (2019) Machine learning methods for systemic risk analysis in financial sectors. Technol Econ Dev Econ 25(5):716-742 https://doi.org/10.3846/tede.2019.8740

Kwiatkowski D, Phillips PCB, Schmidt P, Shin Y (1992) Testing the null hypothesis of stationarity against the alternative of a unit root. J Econ 54(1-3):159-178 https://doi.org/10.1016/0304-4076(92)90104-Y

Lee J, Strazicich MC (2003) Minimum Lagrange multiple unit root test with two structural breaks. Rev Econ Stat 85(4):10821089 https://doi.org/10.1162/003465303772815961

Lee J, Strazicich MC (2013) Minimum LM unit root test with one structural break. Econ Bull 33(4):2483-2492

Li Y, Chen S-Y (2010) The impact of FDI on the productivity of Chinese economic regions. Asia Pac J Account Econ 17(3): 299-312 https://doi.org/10.1080/16081625.2010.9720867

Lipsey, R. E., \& Sjöholm, F. (2010). FDI and growth in East Asia: lessons for Indonesia. IFN Working Paper No. 852, 2010, (852)

Lipsey RE, Sjöholm F (2011) Foreign direct investment and growth in East Asia: lessons for Indonesia. Bull Indones Econ Stud 47(1):35-63 https://doi.org/10.1080/00074918.2011.556055

Louzi BM, Abadi A (2011) The impact of foreign direct investment on economic growth in Jordan. Int J Recent Res Appl Stud 8(August):253-258

Markusen JR, Venables AJ (1999) Foreign direct investment as a catalyst for industrial development. Eur Econ Rev 43(2):335356 https://doi.org/10.1016/S0014-2921(98)00048-8

McNown R, Sam CY, Goh SK (2018) Bootstrapping the autoregressive distributed lag test for cointegration. Appl Econ 50(13): 1509-1521 https://doi.org/10.1080/00036846.2017.1366643

Middleton A (2007) Globalization, free trade, and the social impact of the decline of informal production: the case of artisans in Quito, Ecuador. World Dev 35(11):1904-1928 https://doi.org/10.1016/j.worlddev.2007.02.001

Mujeri MK, Chowdhury $\Pi$ (2013) Savings and investment estimates in Bangladesh: some issues and perspectives in the context of an open economy. Bangladesh Institute of Development Studies (June)

Narayan PK (2005) The saving and investment nexus for China: evidence from cointegration tests. Appl Econ 37(17):19791990 https://doi.org/10.1080/00036840500278103

Ozyigit A, Eminer F (2011) Bounds test approach to the relationship between human capital and foreign direct investment as Regressors of economic growth in Turkey. Appl Econ Lett 18(6):561-565 https://doi.org/10.1080/13504851003742426

Pesaran MH, Shin Y, Smith RJ (2001) Bounds testing approaches to the analysis of level relationships. J Appl Econ 16(3):289326 https://doi.org/10.1002/jae.616

Pesaran MH, Shin Y (1999) An autoregressive distributed lag approach to Cointegration analysis. In: Strom S (ed) Econometrics and Economic Theory in the Twentieth Century. Cambridge University Press, Cambridge

Phillips PCB, Solo V (1992) Asymptotics for linear processes. Ann Stat 20(2):971-1001

Razin A, Sadka E (2003) Gains from FDI inflows with incomplete information. Econ Lett 78(1):71-77 https://doi.org/10.1016/ S0165-1765(02)00179-9

Rugman AM (1985) Internalization is still a general theory of foreign direct investment. Weltwirtschaftliches Arch 121(3):570575 https://doi.org/10.1007/BF02708194

Rugman AM (1986) New theories of the multinational Enterprise: an assessment of internalization theory. Bull Econ Res 38(2): 101-118 https://doi.org/10.1111/j.1467-8586.1986.tb00208.x

Sam CY, McNown R, Goh SK (2019) An augmented autoregressive distributed lag bounds test for cointegration. Econ Model 80:130-141 https://doi.org/10.1016/j.econmod.2018.11.001

Shahbaz M, Rahman MM (2010) Foreign capital inflows-growth Nexus and role of domestic financial sector: an ARDL Cointegration approach for Pakistan. J Econ Res 15:207-231

Shimul SN, Abdullah SM, Siddiqua S (2009) An examination of FDI and growth nexus in Bangladesh: Engle Granger and bound testing Cointgration approach. BRAC Univ J VI(1):69-76 https://doi.org/10.1016/j.ejpb.2008.04.026

Shrestha MB, Chowdhury K (2007) Testing financial liberalization hypothesis with ARDL modelling approach. Appl Financ Econ 17(18):1529-1540 https://doi.org/10.1080/09603100601007123

Silajdzic S, Mehic E (2016) Absorptive capabilities, FDI, and economic growth in transition economies. Emerg Mark Financ Trade 52(4):904-922 https://doi.org/10.1080/1540496X.2015.1056000

Solow RM (1956) A contribution to the theory of economic growth. Q J Econ 70(1):65-94 https://doi.org/10.2307/1884513

Sridharan P, Vijayakumar N, Chandra Sekhara Rao K (2009) Causal relationship between foreign direct investment and growth: evidence from BRICS countries. Int Bus Res 2(4) https://doi.org/10.5539/ibr.v2n4p198

Sunde T (2017) Foreign direct investment, exports and economic growth: ADRL and causality analysis for South Africa. Res Int Bus Financ 41:434-444 https://doi.org/10.1016/j.ribaf.2017.04.035 
Tabassum N, Ahmed SP (2014) Foreign direct investment and economic growth: evidence from Bangladesh. Int J Econ Financ 6(9) https://doi.org/10.5539/ijef.v6n9p117

Urata S (1998) Explaining the poor performance of Japanese direct investment in the United States. Japan World Econ 10(1): 49-62 https://doi.org/10.1016/S0922-1425(96)00254-X

Vu Le M, Suruga T (2005a) Foreign direct investment, public expenditure and economic growth: the empirical evidence for the period 1970-2001. Appl Econ Lett 12(1):45-49 https://doi.org/10.1080/1350485042000293130

Vu Le M, Suruga T (2005b) The effects of FDI and public expenditure on economic growth : from theoretical model to empirical evidence. GSICS Working Pap Ser 2 (November 2005) https://ecommons.luc.edu/cgi/viewcontent.cgi?article= 1008\&context=meea

Wang M (2009) Manufacturing FDI and economic growth: evidence from Asian economies. Appl Econ 41(8):991-1002 https://doi.org/10.1080/00036840601019059

Wu Y (2000) Measuring the performance of foreign direct investment: a case study of China. Econ Lett 66(2):143-150 https:// doi.org/10.1016/S0165-1765(99)00225-6

Zhang KH (2001) How does foreign direct investment affect economic growth in China? Econ Transit 9(3):679-693 https:// doi.org/10.1111/1468-0351.00095

Publisher's Note

Springer Nature remains neutral with regard to jurisdictional claims in published maps and institutional affiliations.

Submit your manuscript to a SpringerOpen ${ }^{0}$ journal and benefit from:

- Convenient online submission

- Rigorous peer review

- Open access: articles freely available online

- High visibility within the field

- Retaining the copyright to your article

Submit your next manuscript at $>$ springeropen.com 